\title{
STUDY OF MUTANT BREAKER VARIETIES ACCORDING TO THE BASIC ECONOMIC-VALUABLE SIGNS UNDER THE CONDITIONS OF KARAKALPAKSTAN
}

\author{
Aytjanov Uzaqbay Echjanovich \\ Candidate of Agricultural Sciences, Senior Researcher, the head of laboratory of the \\ Karakalpakstan Scientific Research Institute of Agriculture. \\ Aytjanov Bakhitjan Uzaqbaevich \\ Doctor of Agricultural Sciences, Senior Researcher of the Karakalpakstan Scientific Research \\ Institute of Agriculture. \\ Sagatdinov Islambek Janabaevich \\ Applicant for the Karakalpakstan Scientific Research Institute of Agriculture, Chimbay, \\ Karakalpakstan, Uzbekistan.
}

Article DOI: https://doi.org/10.36713/epra3424

\begin{abstract}
The mutant varieties M KK-3523 and M KK-3560 turned out to be relatively large-box varieties. These varieties exceeded the standard from +0.1 to +0.3 grams. In the non-irradiated variant, the large-box variety was $K K$ 3547. According to frozen crop from the irradiated variant, the mutant variety $M$ KK-3523 was a relatively highyielding variety when it had an excess of yield against the standard by 10.3\%. In non-irradiated grades KK3536, KK-3548 and KK-3530 for frozen harvest had an excess against the standard from 5.0 to $6.8 \%$.

KEYWORDS: Cotton breeding induced mutagenesis, mutant, radiation dose, mutation, variety, hybrids, cell, yield, precocity, fiber yield, fiber length.
\end{abstract}

\section{INTROUCTION}

Currently, with the help of ionizing radiation, varieties of crops with positive economically valuable traits can be developed at present: cold and frost-resistant, early ripening, with a high content of protein, gluten, nutrients, etc. In India, cotton lines highly resistant to pests were obtained by radio-selection. Mutants with short internodes and female sterility are bred in the USA. A cotton form without gossypol, that is, with a new generic trait, was obtained there, but it was badly damaged by insects. Therefore, forms were created containing gossypol in the leaves and not contained in the seeds. Such varieties are used as a valuable source of protein for the food industry.
In the selection of cotton, it is not customary to identify any specific areas, for example, selection for productivity, precocity, wilt resistance, etc. There is only one goal, the creation of varieties of an intensive type with a complex of the most important economically valuable traits.

Production places high demands on cotton varieties. Varieties should provide large harvests of raw and fiber, characterized by sufficient precocity, resistance to diseases and pests, high yield, length and technological qualities of the fiber, adaptability to machine processing of crops and harvesting. Cotton varieties must have wide adaptability to stress factors

Along with the improvement of agricultural technology of cotton cultivation, accelerated removal 
and introduction into production of early-ripening, more highly productive with a set of characteristics of varieties of agricultural crops, including cotton, is extremely important.

In addition, stable lines can be obtained by altering cellular material under the influence of induced mutagenesis.

It is planned to conduct breeding studies in the conditions of KKSRIA for the breeding of the earliest-growing, highly productive, drought tolerant, high-quality IV-type fiber varieties of cotton for introduction in the northern cotton growing zone of Uzbekistan. The creation of complex resistant varieties with high yield and fiber quality is possible with hybridization and multiple selections of mutant forms of cotton obtained on the basis of several of radiation mutagenesis.

Today, experimenters have at their disposal a vast arsenal of various factors of a physical and chemical nature, with the help of which it is possible to influence the course of morphogenesis in sitespecific hybrids.

With cotton, the first results were obtained by irradiating the second generation of hybrids between variety $108-\mathrm{F}$ and the wild Mexican form 06422 Ibragimov, Tyaminov, [1; 2]. New forms were obtained with many features that are interesting in practical terms.

Irradiation of hybrid plants of the first and third generations in different phases of development: the beginning of budding, the beginning of flowering and mass flowering with doses of 0.5: 1.0 and $2.0 \mathrm{kp}$ contributed to a change in the nature of cleavage, acceleration of the process of formation and increased generation of new characters and properties in subsequent Ibragimov, Tyaminov [1;2].

The above data show that the use of ionizing radiation can be considered as a method of inducing rare recombination in distant hybrids and as a method of obtaining a wide variety of mutations through chromosomal rearrangements.

A combination of induced mutagenesis with hybridization is widely used to obtain a wide range of variability of selection material.

In the course of work, Ibragimov and others [3], using the method of radiation mutagenesis, the mutant lines PM2, PM4, PM5, PM11 were derived, which are 3.8-13.4 centners/ha higher than the control of unirradiated hybrid combinations. Mutant lines are of interest for practical breeding and are successfully used in breeding when breeding new vitro-resistant, precocious varieties of cotton with good fiber quality. Varieties of mutational breeding varieties ML-11 (Karshinsky-1), ML-101 of finefiber cotton (Karshinsky-2) were developed.

\section{METHODS OF CONDUCTING THE EXPERIMENT}

Selection experiments were carried out during 2018-2019 at the experimental base of the Karakalpakstan Scientific Research Institute of Agriculture, located in the northwestern part of the Republic of Uzbekistan. The experience was laid down according to the methodology of the Uzbek Scientific Research Institute of Cotton Breading and Seed located in the city of Tashkent.

On the experimental site, watering irrigation was carried out annually in November-December and in some years in March.

Pre-sowing plowing was carried out by turning the reservoir to a depth of $25-30 \mathrm{~cm}$, followed by harrowing and shorting in 2 tracks.

Selection crops were carried out manually according to the market line of the seeder to a depth of $4-5 \mathrm{~cm}$, according to the scheme $60 \times 25-1$. In the developmental phase of 2-3 true leaves, germination of seedlings was carried out, leaving one sown manually, in $4^{x}$ multiple repetition in two rows, the options were randomized.

Based on the previously created breeding materials, our breeders in the cotton breeding laboratory for 2 years laid the experience of station cotton variety testing at the experimental site of the Karakalpakstan Scientific Research Institute of Agriculture.

\section{RESEARCH RESULTS AND THEIR DISCUSSION}

The studied varieties of station variety testing of cotton by the main economically valuable characteristics are shown in Table-1.

Noted: MKK - mutant varieties obtained from irradiation of cotton seeds with a dose of 3000 $\mathrm{r} / \mathrm{sec}$. KK - derived varieties without irradiated variant. S-4727 - control grade.

It should be noted that in the varieties under study for station cotton varietal tests during the growing season, most varieties comparatively deviated towards late maturity. Since in addition to some varieties KK-3532 and the mutant KK-3523, they were late ripe for +2.0 and +4.0 days. The tabular data show that by weight of the raw material of one box of the cultivar without the irradiated variant, most varieties deviated towards the smallboxed parent from -0.1 to 0.5 grams against the standard cultivar S-4727. Mutant varieties MKK-3523 and the mutant MKK-3560 turned out to be relatively large-box varieties. These varieties are stranded excess against the standard from +0.1 to +0.3 grams. Of the non-irradiated versions, the large box variety was KK-3547. According to the frozen crop from the irradiated variant, the mutant variety KK-3523 was a 


\section{EPRA International Journal of Research and Development (IJRD)}

relatively high-yielding variety when it had an excess of productivity against the standard by $10.3 \%$, without irradiated varieties, this trait was preserved in varieties KK-3536, KK-3548 and KK-3530 had excess against the standard from 5.0 to $6.8 \%$. The remaining varieties on this basis were relatively low or had a slight excess against the standard S-4727. According to the opened boxes, the majority of varieties were also relatively high-yielding varieties against the

Table 1.

The main economically valuable features of the station variety testing of cotton

\begin{tabular}{|c|c|c|c|c|c|c|c|c|c|c|c|c|c|}
\hline \multirow[b]{3}{*}{ № } & \multirow[b]{3}{*}{ Varieties } & \multirow{2}{*}{\multicolumn{2}{|c|}{$\begin{array}{l}\text { Vegetation } \\
\text { period. }\end{array}$}} & \multirow{2}{*}{\multicolumn{2}{|c|}{$\begin{array}{l}\text { The mass of } \\
\text { raw } 1 \text { boll. gr }\end{array}$}} & \multicolumn{4}{|c|}{ The harvest of cotton raw, c/ha. } & \multirow{2}{*}{\multicolumn{2}{|c|}{$\begin{array}{c}\text { Fiber outlet, } \\
\%\end{array}$}} & \multirow{2}{*}{\multicolumn{2}{|c|}{$\begin{array}{c}\text { Fiber length, } \\
\text { mm. }\end{array}$}} \\
\hline & & & & & & \multicolumn{2}{|c|}{ froz. } & \multicolumn{2}{|c|}{ Gone.boll. } & & & & \\
\hline & & Days. & $\begin{array}{l}\text { Rejec- } \\
\text { tion }\end{array}$ & gr. & $\begin{array}{l}\text { Reject- } \\
\text { tion }\end{array}$ & c/ha & $\begin{array}{c}\text { Rejec- } \\
\text { tion in \% }\end{array}$ & c/ha & $\begin{array}{c}\text { Rejec- } \\
\text { tion in } \\
\%\end{array}$ & $\%$ & $\begin{array}{c}\text { Rejec- } \\
\text { tion in } \\
\%\end{array}$ & Mm & $\begin{array}{c}\text { Rejec- } \\
\text { tion in } \\
\%\end{array}$ \\
\hline 1 & S-4727 & 110 & & 6.3 & & 23.2 & & 25.4 & & 36.1 & & 32.3 & \\
\hline 2 & КК-3532 & 109 & -1 & 6.0 & -0.3 & 23.9 & 103.0 & 26.0 & 102.3 & 36.4 & +0.3 & 32.7 & +0.2 \\
\hline 3 & КК-3548 & 110 & \pm 0 & 6.3 & \pm 0 & 24.8 & 106.8 & 29.6 & 116.5 & 37.0 & +0.9 & 33.0 & +0.5 \\
\hline 4 & MKK-3560 & 113 & +3 & 6.6 & +0.3 & 20.4 & 87.9 & 25.8 & 101.5 & 37.1 & +1.0 & 33.4 & +0.9 \\
\hline 5 & КК-3535 & 109 & -1 & 6.0 & -0.3 & 23.7 & 102.1 & 29.6 & 116.5 & 36.0 & -0.1 & 32.8 & +0.3 \\
\hline 6 & КК-3536 & 110 & \pm 0 & 5.9 & -0.4 & 24.9 & 105.0 & 29.3 & 114.0 & 36.4 & +0.3 & 32.1 & -0.4 \\
\hline 7 & КК-3537 & 112 & +2 & 6.1 & -0.2 & 19.0 & 81.8 & 24.4 & 96.0 & 36.7 & +0.6 & 32.6 & +0.1 \\
\hline 8 & КК-3552 & 113 & +3 & 5.8 & -0.5 & 24.4 & 105.1 & 32.2 & 126.7 & 36.1 & \pm 0 & 32.0 & -0.5 \\
\hline 9 & КК-3546 & 113 & +3 & 6.4 & +0.1 & 20.3 & 87.8 & 27.3 & 107.4 & 35.8 & -0.3 & 33.0 & +0.5 \\
\hline 10 & КК-3547 & 114 & +4 & 6.6 & 0.3 & 22.7 & 95.7 & 26.8 & 104.2 & 36.9 & 0.7 & 32.9 & 0.6 \\
\hline 11 & MKK-3523 & 109 & -1 & 6.4 & 0.1 & 25.6 & 110.3 & 31.0 & 122.0 & 36.5 & 0.3 & 32.6 & 0.3 \\
\hline 12 & KK-3530 & 113 & +3 & 6.2 & -0.1 & 25.3 & 106.7 & 29.7 & 115.5 & 36.7 & 0.5 & 32.3 & 0.0 \\
\hline 13 & КК - 3531 & 112 & +2 & 6.3 & \pm 0 & 21.7 & 91.5 & 24.7 & 96.0 & 36.4 & 0.2 & 32.3 & 0.2 \\
\hline
\end{tabular}

According to the output of the fiber in studied varieties, most were high-outlet sorts versus to the standard one. From those high-yield varieties were mutant MKK-3560. This variety had a fiber yield of $37.1 \%$ when the S-4127 standard was $36.1 \%$. The remaining varieties were a slight excess against the standard. In terms of fiber length mainly most of the studied varieties were found to be relatively longfiber varieties against the standard. From the irradiated cultivars, this trait ranged from 0.3 to 0.9 $\mathrm{mm}$ higher against the standard. Without the irradiated variant, the long-fiber varieties were KK3535, KК-3548, КK-3546 and KK-3547. These varieties ranged length from +0.3 to $+0.6 \mathrm{~mm}$.

In general, according to the main economically valuable traits in the station variety of cotton, the relatively best varieties were the МКК3523 mutant and without the irradiated KK-3548 variety.

\section{CONCLUSIONS}

1. Mutant varieties MKK-3523 and MKK3560 appeared in comparison with large-boll varieties against the control variety $\mathrm{S}-4727$; these varieties had a reliable habit against the standard standard S-4727. These varieties were KK-3548, KK3535, KK-3552 and KK-3530. They had a harvest of open-boxes and exceeded the standards from $15.5 \%$ to $26.7 \%$. In the irradiated cultivars, the MKK-3523 mutant and the MKK-3560 mutant, according to this criterion had yields from $+14.0 \%$ to $+22.0 \%$ higher compared to the standard variety $\mathrm{S}-4727$.

from +0.1 to +0.3 grams against the control variety S-4727.

2. Based on the productivity of the frozen crop, the MKK-3523 mutant was a relatively highyielding variety, when it had a $10.3 \%$ higher yield against the control.

3. It should be noted that, according to the main economic valuable attribute, the mutant grade MKK-3523 and without the irradiated grade KK3548 were found to be relatively better.

\section{REFERENCES}

1. Tyaminov A.R. (2000), Questions of cotton genetics, selection and seed production of cotton and alfalfa. "An early ripened finefiber variety of cotton for intensive farming". "UzGSUITI". Tashkent, p.p: 111.

2. Ibragimov Sh.I., Kovalchuk R.I., Zokirov S. (2000), Questions of genetics, selection and seed production of cotton and alfalfa. "Practical results of experimental mutagenesis", "Hamkor-business", Tashkent, p.p: 177.

3. Ibragimov Sh.I., Kovalchuk R.I., (1976), Questions of genetics, selection and seed production of cotton and alfalfa (edition 132). "The use of irradiation in cotton breeding”, “Uzgiprozem”, Tashkent, p.p: 20. 